\title{
INDIVIDUAL INTERPRETATIONS AS INSTRUMENTS FOR UNIFORM APPLICATION OF TAX LAW BY THE TAX ADMINISTRATION
}

One of Roman's legal principles state that Leges ab omnibus intellegi debet (statutes should be intelligible to all). The above mentioned postulate is of universal nature and may with full certainty be referred to the legislator who makes law within the scope of Public Finances. Undoubtedly, the problem of clarity and transparency of the law being made constitutes an important and practical issue in the 21st century in Poland and other European countries as well. However, we should have in mind that even the best act that takes into account the above principle, from the moment it becomes valid onwards, constitutes a certain "element" of the whole system of law. As a result, considering mutual relations between various regulations, dynamics of socio-economic changes in practice, there may occur various phenomena of different interpretation and application of law by the administration and citizens. In this situation, it seems to be necessary that some mechanism should function in financial law, which will allow elimination of or at least considerable limits to this phenomenon. In this paper the institution of individual interpretation has been outlined, based on the tax law example, that may serve to meet the goal indicated in the subject-matter.

The central authority of the tax administration in Poland, i.e. the Minister of Finance (MF) pursuant to the rules of the Tax Ordinance Act (TOA) ${ }^{1}$, is obliged to take actions to ensure uniform application of the tax law by tax authorities and tax investigation authorities. TOA's regulations in force do not contain a closed list of methods, forms or means used to meet the above goal. In Art. 14a of the TOA, the legislator pointed out as an example only one of the methods of striving by MF for ensuring uniform application of the tax law by the tax administration. The above mentioned regulation of the TOA gives MF a responsibility to make general interpretations of the tax law. On such interpreting, MF in the process of

1 Act of 29 August 1997, Tax Ordinance (uniform text: Journal of Laws of 2005, no. 8, item 60, as amended, hereinafter referred to as TOA), entered into force on 1 January 1998. 
interpretation should take into account judicial decisions of common courts of law and the Constitutional Tribunal as well as the European Court of Justice. Art. 14 i of the TOA charges the MF with a duty to publish a general interpretation in the Official Gazette of the MF without delay and to publish it in the Public Information Bulletin (BIP- an official electronic periodical). Publication of general interpretations in the MF Official Gazette is necessary to cause specific legal effects related to protection provided by the rules of law for interested entities that comply with the content of a general interpretation. The date of publication in an official gazette also sets the starting moment from which tax administration authorities should observe the general interpretation in consideration of tax cases with the purpose of uniform application of the tax law. Furthermore, publication of information in the MF official gazette makes it available for tax administration bodies and current and future taxpayers, tax remitters, tax collectors or other entities charged with various tax obligations. Publication of general interpretations in BIP makes them more available and this publication constitutes an additional official source of information on their contents for the fiscal administration and entities charged with tax obligations as well.

In the literature on the subject it is suggested that second instrument, beside general interpretations, that may unify application of the tax law by the fiscal administration, is the institution of individual interpretation regulated by Art 14b-14p of the $\mathrm{TOA}^{2}$. It should be noted, however, that the regulations of law in force do not indicate directly individual interpretations as a means serving uniform application of the tax law by tax authorities and tax investigation authorities. Pursuant to Art. 14b $\S 1$ of the TOA, MF shall issue, at a written request of the interested party, a written interpretation of tax law regulations, i.e. individual interpretation. Depending on the contents of the request, the interpretation expresses a position of the MF on how to interpret and apply provisions of the tax law in an existing individual case of an interested party and with regard to individual facts of the case or in a situation in which the person submitting the request may be in the future.

The MF issues individual interpretations with regard to taxes the calculation and collection (investigation) of which fiscal administration bodies subordinated to MF are competent for. But as regards taxes the calculation and collection of which tax bodies of territorial self-government are competent for, individual interpretations are issued by these entities (i.e. commune head, mayor and town president, district governor or voivodeship marshal (Art. $14 \mathrm{j} \S 1$ of the TOA $)^{3}$ ). Individual interpretation contains an opinion of the MF or a territorial self-government authority of first Komentarz (The Tax Ordinance Act - Commentary), Toruń 2007, p. 76

3 In the present tax system in Poland territorial self-government tax bodies of first instance with the right to calculate and collect taxes are: commune head, mayor and town president. Therefore, in practice only these authorities will issue individual interpretations at the request of interested parties. 
instance on how the regulations the interested party requests should be understood and how they should be applied to the individual current or future (possible) facts of the case. As a result, individual interpretation, as opposed to general interpretation, is not of general nature and the direct purpose of its issuance is not to unify tax law application by the fiscal administration but to inform an individual recipient how this administration understands and shall apply tax law regulations in the situation presented in the request. Whereas the interested party has a guarantee that if he/ she complies with the individual interpretation, he/she shall not suffer negative consequences of such action as punishment for a tax offense or transgression, shall not pay default interest by virtue of a tax unduly paid or, in certain situations, shall be relieved from the duty to pay tax within the scope that is a subject of the interpretation.

It should be pointed out, however, that apart from general interpretations, also individual interpretations are published in BIP. Such duty results from Art. $14 \mathrm{i} \S 3 \mathrm{TOA}$, and an individual interpretation with a request to issue it, without identification data of the person submitting the request and other entities mentioned in the interpretation. Deletion of individual data of the person submitting the request and other entities will cause that individual interpretations, on publishing in BIP, will gain features of general interpretations ${ }^{4}$. As a result, taking into account easy access to individual interpretations published in BIP, tax authorities and tax investigation authorities in applying tax law and deciding individual tax cases undoubtedly will take advantage of interpretation directives they comprise. It may be presumed that the importance and scope of influence of individual interpretations on uniformity of application of the tax law by the fiscal administration will be differentiated depending on which tax authority is an author of the individual interpretation, i.e. MF or a territorial self-government tax authority of first instance, and which tax authority - subordinated to MF or not, like territorial self-government tax authorities - will seek interpretational directives in individual interpretations in application of tax law regulations. This differentiation is related to the system of issuing individual interpretations, introduced in Poland on 1 July 2007. Before this date, regardless of what $\operatorname{tax}^{5}$ the request for a written interpretation referred to, in individual case of the requesting entity the competent tax authority to reply to make individual interpretation was in principle a tax authority of first instance. They were tax office heads and customs office heads as tax authorities of first instance - as regards taxes collected by these authorities - subordinated to MF as the central authority of the tax administration and commune head, mayor and town president, district governor or voivodeship marshal as territorial self-government tax authorities of

\footnotetext{
4 Compare, e.g.: B. Adamiak, J. Borkowski, R. Mastalski, J. Zubrzycki, Ordynacja podatkowa. Komentarz (The Tax Ordinance Act - Commentary), Wrocław 2007, pp.153-154 
first instance within their competence. The presented model of issuance of individual interpretations was a centralized one. It was widely criticized because, due to a great number of tax authorities entitled to issue individual interpretations, in practice there were situations of discrepant or even contradictory interpretations with regard to similar facts. In the literature it is emphasized that such a system of issuance of individual interpretations led to territorial differentiation of tax justice ${ }^{6}$, which in practice could lead to a situation that one person in a similar situation as regards legal fiscal facts of a case was charged with tax according to the interpretation by the tax authority, while the other for whom the competent was another authority, was not. Of course, such a situation cannot be accepted from the point of view of the constitutional principle of equality before the law expressed in Art. 32, exc. 1 of the Constitution of the Republic of Poland, pursuant to which: 'All persons shall be equal before the law. All persons shall have the right to equal treatment by public authorities." ${ }^{7}$

As a result, an accidental circumstance which is competence of a tax authority requested for an individual interpretation cannot shape tax rights and duties of entities applying for such interpretation. It should be noted that before 1 July 2007, in the Polish legal system a mechanism functioned that, at least within some scope, allowed for removal of contradictory interpretations from legal transactions, and by this to some extent in practice influenced uniformity of application of the tax law by tax authorities. Pursuant to Art. 14a $\S 4$ TOA in wording that was in force before 1 July 2007, giving interpretation with regard to the scope and manner of application of the tax law in individual case of the entity requesting, the interpretation was made in the course of an administrative act, i.e. a decision with the right to appeal. Appeal authorities (second instance authorities) had competences of appeal proceedings and supervision as follows: head of tax chamber with regard to interpretative decisions issued by head of tax office, head of customs chamber with regard to decisions of a customs office head, and self-government appeal council with regard to decisions of commune head, mayor and town president, district governor or voivodeship marshal.

The above mentioned authorities might change or repeal interpretative decisions of a tax authority of first instance in the course of a decision following an appeal lodged by the recipient of the decision. A condition for a change or repeal of an interpretative decision was determination by the appeal authority that the lodged appeal needed to be considered (Art. $14 \mathrm{~b} \S 1$ TOA in the wording that was in force before 1 July 2007). In the second procedure used as a means of supervision, the appeal authority might commence ex officio (officiality principle) the procedure of 
a change or repeal of a decision comprising interpretation if this decision was a gross breach of law, judicial decisions of the Constitutional Tribunal or European Court of Justice, or such lack of compliance of the interpretation with the law was a result of a change of legal status (Art. $14 \mathrm{~b} \S 5$ point 2 TOA in the wording that was in force before 1 July 2007). As a result, applying the two above mentioned procedures an appeal authority had the possibility of eliminating from legal transactions provisions comprising discrepant or contradictory interpretation of tax law provisions in similar factual situations. This was made by a decision in which an appeal authority decided about the merits of the case differently from the tax authority of a lower instance by changing the interpretative decision and presenting its own different point of view on the meaning of the provisions that were subject to interpretation. But a repeal of the decision of an authority of first instance constituted a decision of cassation nature, where an appeal authority did not interpret tax law provisions.

However, the removal of varying (contradicting) individual interpretations was (or could have been) carried out within the jurisdiction of an adequate second instance tax authority which was able to supervise and influence the content (explanation) of interpretations issued by first instance tax authorities located within its jurisdiction. The aforementioned procedures of eliminating incorrect interpretations, as well as the obligation of placing final interpretation resolutions and decisions on Internet pages of adequate fiscal or customs departments following the removal of the applicant's identification, allowed to unify the application of the tax law among at least first instance tax authorities subordinate to a given appeal authority. This visibly did not provide a final solution for the problem of peculiar "regionalisation" of tax interpretations, i.e. possibilities of various explanations of the tax law in similar or identical actual states.

It is possible to say that this was a shift of the problem to a "higher level", since while it is possible to unify the application of the law by first instance tax authorities in the property range of a given appeal authority, there is no guarantee of eliminating differing interpretations and unambiguous application of the tax law by first instance tax authorities subordinate to various appeal authorities. Also the legal explanation performed by appeal authorities in issued decisions amending interpretative resolutions could have been inconsistent, and in consequence the appeal authorities could have applied the tax law non-uniformly. The resulting situation could have seen the existence of at least two contradictory individual interpretations within the country, due to being issued by, e.g., different appeal authorities presenting inconsistent problem explanation to the regulation applicant. The aforementioned negative results of the significant existing number and variety of tax authorities empowered to issue individual interpretations, i.e. being a somewhat natural result of the decentralised system, can be eliminated by assignation of such empowerments to a single tax authority. It should be indicated that Polish legal regulations on issuing 
individual interpretations binding prior to July 12007 also carried, although in a very limited range, a centralised model for issuing individual interpretations. ${ }^{8}$

On September 1 2005, the MF was equipped with competences of issuing written interpretations in individual cases, exclusively in the scope of agreement resolutions on evasion of double taxation and other ratified international agreements on tax issues. Within the aforementioned scope, this was the only main administration authority - with exclusion of first or second instance tax authorities - empowered to issue individual interpretations. In this case, the legislator recognized the demands presented in the literature regarding empowering the central authority, i.e. the MF, for execution of individual interpretations of the tax law (although in limited range), instead of first instance tax authorities. ${ }^{9}$ At this time, i.e. since July 12007 , there is a dual system of issuing individual interpretations effective in Poland. Individual interpretations for taxes subject to execution and collection by self-government tax authorities are issued by these first instance authorities. Therefore, in relation to these taxes (public levies), a decentralized model of issuing individual interpretations is still active. Contrarily to the previous procedure, the present procedure of issuing such interpretations excludes self-government appeal courts as second instance tax authorities. The binding legal state sees appeal authorities released of competences in the scope of instance control or in mode of individual interpretation supervision.

The literature indicates difficulty of implementing a centralized interpretation issuing model in relation to taxes collected by self-government tax authorities due to the peculiarity of such taxes, which are also formed by regional legal acts (on rates, tax exemptions). ${ }^{10}$ While agreeing with this observation, it should be noted that, in relation to individual interpretations issued by self-government tax authorities, the problem of conflicting interpretations functioning within legal turnover remains unresolved, which may lead to territorial differentiation of tax justice. In consequence, due to the aforementioned real threats of issuing different individual interpretations by various self-government tax authorities, the influence of such interpretations, published in BIP, on the standardization of tax law applied by tax authorities may be limited. It seems that, in relation to individual interpretations issued by first instance self-government tax authorities, the legislator abandoned the possibility of their verification by appeal authorities, i.e. by self-government appeal courts, too hastily. While they are currently not executed as before in a form of a resolution, this change did not obstruct the self-government appeal courts from retaining the possibility

8 Compare, e.g.: Z. Czajka, Wiążące interpretacje prawa podatkowego Ministra Finansów w Polsce, in: . И.B. Гущин (editor), Финансовое правотворчество и правоприменение в государствах Центральной и Восточной Европы, Grodno 2006, p. 68.

9 E. Ruśkowski, J. Salachna, Problemy konstrukcji i stosowania przepisów o wiążących interpretacjach prawa podatkowego, in: H. Dzwonkowski (editor), Procedury podatkowe - gwarancje procesowe czy instrument fiskalizmu?, Warsaw 2005, p. 29 
of changing or repealing individual interpretations. This solution, as shown above, was certainly imperfect, however, it allowed more effective (full) standardization of tax law application by self-government tax authorities than the one currently in place. This is because the legal system lacks a mechanism allowing elimination of contradictory interpretations at the activity level of fiscal administration. The possibility of appealing against individual interpretations issued by first instance self-government tax authorities to the administration court seems to be insufficient since judicial decisions may influence uniform application of the tax law by tax authorities only indirectly and with certain delay. Many interpretation problems could be solved during proceedings before the self-government appeal court, with no need to engage the court of law.

As previously pointed out, for taxes subject to execution and collection by selfgovernment tax authorities, since July 1 2007, the tax authority issuing individual interpretations is the MF. In consequence, a centralized model of issuing individual interpretations was adopted here. However, it is noticeable that, in case of taxes collected by national government tax authorities, we are dealing with only a formal, not actual, concentration of individual interpretation issuing competences in range of a single central tax authority, which is the MF. In compliance with binding regulations, to assure uniformity of issuing binding (individual) interpretations and improvement of applicant service, the MF may, by way of a resolution, empower subordinate authorities to issue individual interpretations in its name and within a defined scope, simultaneously determining the material and local property of the authorities (Art. 14b $\S 6$ O.p.). The MF exercised its empowerments and authorized four (of sixteen) fiscal department directors, i.e. in Bydgoszcz, Katowice, Poznan and Warsaw, to issue individual interpretations in its name. ${ }^{11}$ Therefore the real tax authority issuing individual interpretations is not the MF as a central authority of fiscal administration, but the four second-instance tax authorities. In consequence, in such a case it is impossible to speak of full centralization of issuing individual interpretations, although the number of tax authorities empowered to issue such interpretations has been significantly limited.

In consequence, the danger of contradictory interpretations appearing in legal turnover has been greatly limited, although such situations cannot be excluded completely. A possible organizational solution to eliminate (or significantly limit) issuing of discrepant or contradictory individual interpretations by empowered fiscal department directors is to entrust the compilation of such interpretations to specialist cells active within the aforementioned fiscal departments, since the National Tax

11 Rozporządzenie Ministra Finansów z dnia 20 czerwca 2007 r. w sprawie upoważnienia do wydawania interpretacji przepisów prawa podatkowego - Decree of the Minister of Finance of June 202007 on empowerment of issuing interpretations of tax law regulations (Journal of Laws no. 112, item 770) 
Information (KIP) offices have been founded in these departments. ${ }^{12}$ The tasks of these offices, besides compilation of written interpretation of tax law regulations at the request of the interested party, specifically include: providing general tax information by phone or e-mail and cooperation with the Ministry of Finance and fiscal departments in monitoring uniformity of tax law application ( $\S 4$ of the MF ruling). It should be noted that, during provision of phone information, the workers of such offices come into contact with various actual states. In order to guarantee information uniformity, they utilize a common application, i.e. the Handbook of Questions and Answers. Since the Handbook database is updated in real time, every employee has access to uniform information, regardless of their location. The database is complied by KIP employees, while questionable issues are handled by appropriate departments of the Ministry of Finance. The content of this application may also serve as the foundation for correctness verification and assurance of uniformity of issued individual interpretations. The aforementioned factors justify the assumption that the role of individual interpretations issued by the MF, in the scope of uniform application of the tax law, will be much more significant and effective than that of individual interpretations issued by first instance self-government tax authorities. The hierarchical subordination of national government tax authorities, which treat the explanation of legal regulations of individual interpretations as the official stance of the central authority of tax administration, will also be important in this case.

The binding legal regulations compel the MF to pursue assurance of a uniform tax law by fiscal administration, but do not limit this obligation to national government tax authorities. The content of Art. 14a O.p. provides the conclusion of this obligation also encompassing self-government tax authorities. Without a doubt, general interpretations are an instrument for the achievement of uniform application of the tax law by self-government tax authorities. The MF may also issue such interpretations in relation to taxes subject to execution and collection by selfgovernment tax authorities. These authorities, while not hierarchically subordinate to the MF, may consider general interpretations issued by this central tax authority in decisions concerning tax cases. The factors for persuasion of self-government tax authorities to comply with general interpretations, may be their issuing authority and convincing arguments included in such interpretations. ${ }^{13}$ In turn, the role of individual interpretations in the collection of MF resources for assurance of uniform application of the law by fiscal administration (even though this is not their main goal) will be limited to national government tax authorities. This is because the MF

12 Zarządzenie Nr 13 Ministra Finansów z dnia 20 czerwca 2006 r. w sprawie organizacji urzędów i izb skarbowych oraz nadania im statutów - Decree no. 13 of the Minister of Finance of June 202006 on organization of fiscal departments and offices and on providing them with legal status (Journal of Laws MF. no. 7, item 55 as amended, hereinafter referred to as the MF decree) podatkowe, in: H. Litwińczuk (editor), Prawo podatkowe przedsiębiorców, Warsaw 2006, p. 58. 
is competent to issue individual interpretations only in the scope of taxes collected by these authorities. Consequently, in relation to self-government tax authorities, the MF will not be able to influence uniform application of the tax law by these authorities through individual interpretations due to a lack of adequate empowerments. Of course, the individual interpretations issued by self-government tax authorities may influence standardization of the tax law application by the tax administration, but this will occur without the involvement of the MF. Therefore, at their current legal state, individual interpretations of self-government tax authorities are not a resource for assurance of uniform application of the tax law in the scope of the MF fulfilling its imposed obligations. 


\section{Streszczenie}

Przedmiotem niniejszego opracowania jest instytucja indywidualnych interpretacji wydawanych przez ministra finansów oraz w pierwszej instancji - przez samorządowe organy podatkowe $\mathrm{w}$ kontekście zapewnienia przez organy administracji podatkowej jednolitego stosowania prawa podatkowego. Należy bowiem pamiętać, że nawet najlepiej skonsturowana ustawa stanowi tylko „element” całego systemu prawnego razem z jej upoważnieniami. W rezultacie, uwzględniając wzajemne relacje różnych regulacji oraz zmiany społeczne i ekonomiczne, mogą zdarzać się przypadki różnych interpretacji i stosowania prawa przez administrację i obywateli. W tej sytuacji wydaje się niezbędnym wprowadzenie do systemu prawnego mechanizmu, który pozwoli znacząco eliminować takie przypadki. Narzędziem do osiagnięcia tego celu może być instytucja indywidualnych interpretacji. 